\title{
Evapotranspiration and water response function of squash cv. 'Italiana' under different cultivation conditions
}

\author{
Charles C. Martim ${ }^{1}$, Suzana G. da Silva ${ }^{1}$, Brena G. Ferneda ${ }^{1}$, \\ Adilson P. de Souza ${ }^{1}$, Andréa C. da Silva ${ }^{1} \&$ Mariana Pizzatto $^{1}$ \\ ${ }^{1}$ Universidade Federal de Mato Grosso/Instituto de Ciências Agrárias e Ambientais. Sinop, MT. E-mail: charleschp2011@hotmail.com - ORCID: \\ 0000-0003-2955-0105; suzanagrassis@gmail.com - ORCID: 0000-0003-3027-1621; brenaferneda95@gmail.com - ORCID: 0000-0001-8928-211X; \\ pachecoufmt@gmail.com (Corresponding author) - ORCID: 0000-0003-4076-1093; andcar1007@gmail.com - ORCID: 0000-0003-2921-3379; \\ marianapizzatto23@gmail.com - ORCID: 0000-0001-5751-0368
}

\section{Key words:}

crop coefficients

mulching

irrigation management

\begin{abstract}
A B S T R A C T
Aiming to support projects and managements of irrigation for vegetables in the MidNorth region of Mato Grosso state, Brazil, this paper determined crop evapotranspiration (ETc), crop coefficients $(\mathrm{Kc})$ and water response function of summer squash (Curcubita pepo) cv. 'Italiana' under different cultivation conditions. The plantations were conducted in the dry season of the region (July to October 2016), using $2.5 \mathrm{~kg} \mathrm{~m}^{-2}$ of millet straw (grass) and crotalaria straw (legume) and bare soil. ETc was obtained by soil water balance through tensiometry, whereas Kc values were given by the ratio between ETc and the reference evapotranspiration (ETo) obtained by the FAO-56 Penman-Monteith method. For the water response function, the rates of $40,60,80,100$ and $120 \%$ ETc were applied, in which case the Class A pan method was used to obtain ETo. The different soil covers did not influence the ETc, Kc and accumulated thermal sum in the phenological stages of the summer squash. Kc values were $0.1,0.25,0.38$ and 0.41 , for the phenological stages I to IV, with average durations of $8,46,16$, and 20 days, respectively. Increase in irrigation depths did not influence the rates of production of male and female flowers, but affected yield and decreased water use efficiency, regardless of soil cover.
\end{abstract}

\section{Palavras-chave:}

coeficientes de cultivo cobertura morta manejo de irrigação

\section{Evapotranspiração e função de resposta hídrica da abobrinha cv. Italiana em diferentes condições de cultivo}

\section{R E S U M O}

Buscando subsidiar projetos e manejos de irrigação para hortaliças na região do Médio-Norte de Mato Grosso, determinou-se a evapotranspiração da cultura (ETc), os coeficientes de cultivo (Kc) e a função de resposta hídrica da abobrinha cv. Italiana (Curcubita pepo) em diferentes condições de cultivo. Os plantios foram conduzidos na estação seca da região (julho a outubro de 2016), com uso de $2,5 \mathrm{~kg} \mathrm{~m}^{-2}$ de palhadas de milheto (gramínea) e crotalária (leguminosa) e solo descoberto. A ETc foi obtida pelo balanço hídrico do solo por tensiometria, enquanto que os valores de Kc foram dados pela razão entre ETc e a evapotranspiração de referência (ETo) obtida por Penman-Monteith FAO-56. Para a função de resposta hídrica foram aplicadas as lâminas de 40, 60, 80, 100 e 120\% da ETc, sendo que nesse caso, empregou-se o método do tanque classe A para obtenção da ETo. As diferentes coberturas do solo não influenciaram na ETc, Kc e soma térmica acumulada nas fenofases da abobrinha. Os valores de Kc foram de 0,$1 ; 0,25 ; 0,38$ e 0,41, para as fenofases de I a IV, com durações médias de 8, 46, 16 e 20 dias, respectivamente. $\mathrm{O}$ aumento da lâmina irrigada não influenciou nas taxas de emissão de flores masculinas e femininas, mas afetou a produtividade e diminuiu a eficiência do uso da água, independentemente da cobertura do solo. 


\section{INTRODUCTION}

Under Brazilian conditions, vegetable production is based and depends on intensive soil preparation, which alters its physical-hydraulic characteristics and exposes it to wide micrometeorological variations along the day and along the production cycle (Román-Paoli et al., 2012; Echer et al., 2014). Besides that, the adoption of production systems that involve economic, environmental and social aspects and seek managements which allow the conservation of natural resources has been recommended in the substitution of conventional production systems, especially in vegetable production (Souza et al., 2014).

Regardless of the cultivation system adopted, vegetable production depends on numerous factors, but the response to water availability can be directly influenced by the quantity and frequency of irrigation, water application method, crop development stage, soil physical-hydraulic conditions and microclimatic conditions (Ertek et al., 2004; Souza et al., 2014).

Thus, for an efficient management of irrigation water it is fundamental to know the water needs of the crop in its different phenological stages, given by the potential evapotranspiration along with water response functions (Amer et al., 2009; Yavuz et al., 2015a, b; Seymen et al., 2016).

Despite the existence of tabulated values and fitting equations to correct crop coefficients - Kc (Allen et al., 1998; Maughan et al., 2015), the variations in the development rates of the crops when subjected to new cultivation systems, combined with edaphoclimatic variations, demonstrate the need for local determinations, avoiding the use of generalized recommendations which may lead to water deficit or excess.

Therefore, the objective was to determine potential evapotranspiration (ETc), crop coefficients $(\mathrm{Kc})$ and water response function of summer squash cv. 'Italiana' (Cucurbita pepo) subjected to three cultivation conditions, in the MidNorth region of Mato Grosso, Brazil.

\section{Material AND Methods}

The experiment was conducted in the Plant Production Sector of the UFMT, University Campus of Sinop (11.85 S; $55.38^{\circ} \mathrm{W} ; 371 \mathrm{~m}$ ), in a dystrophic Red Yellow Latosol (EMBRAPA, 2013), between July and October 2016. According to Köppen's classification, the climate of the region is Aw (hot and humid tropical), with two well-defined seasons: rainy (October to April) and dry (May to September). Mean annual rainfall and potential evapotranspiration are 1974.77 and $1327.29 \mathrm{~mm}$, respectively, and mean monthly temperatures oscillate between 23.2 and $25.8^{\circ} \mathrm{C}$ (Souza et al., 2013).

During the experiment, meteorological variables were measured by an automatic stations with the following sensors: PAR radiation (LI-COR) at $2 \mathrm{~m}$ height from the soil, wind speed and direction (anemometer, 03002-L RM Young) at $10 \mathrm{~m}$ height, psychrometer with thermometer shelter (Vaisala, CS 215) at $2 \mathrm{~m}$ height, pluviograph (TE 525) at $1.5 \mathrm{~m}$ height and heliograph. Data acquisition was carried out using a CR1000 datalogger operating at $1 \mathrm{~Hz}$ frequency and storing means of 300 readings or $5 \mathrm{~min}$.
Three cultivation conditions were evaluated: no cover (bare soil), soil covered with straw of millet (Pratylenchus brachyurus), and soil covered with straw of crotalaria (Crotalaria juncea), with average layer of $2.5 \mathrm{~kg} \mathrm{~m}^{-2}$. To form this layer of plant residues, both crops were planted in the experimental plots and two cuts were performed before the production of the first flowers, and the biomass generated was chopped and dried in the shade. After growing these previous crops, the experiment was carried out in two steps: i) sowing on July 4, 2016, to obtain evapotranspiration measurements and define crop coefficients; ii) sowing on July 18, 2016, to apply different irrigation depths.

In the evaluation of evapotranspiration, the experimental plots were installed in a randomized block design with four replicates (12 plots with $15 \mathrm{~m}^{2}$ and 14 plants evaluated in each). On the other hand, in the evaluation of water response function, a $5 \times 3$ factorial scheme was used (irrigation depths $\mathrm{x}$ soil cover) in split plots, with three replicates (subplots with $12 \mathrm{~m}^{2}$ and 8 plants evaluated in each).

The summer squash (Cucurbita pepo) cultivar 'Italiana' was used, which has a clump-shaped crown, erect growth, short size and cylindrical fruits. The holes were $0.2 \times 0.2 \times 0.4 \mathrm{~m}$, with spacings of $1.0 \times 0.75 \mathrm{~m}$ (between rows and between plants). Physical and chemical characterizations of the soil were carried out based on the recommendations of Teixeira et al. (2017). The soil had the following conditions in the $0-20$ and $20-40 \mathrm{~cm}$ layers: $\mathrm{pH}$ in $\mathrm{H}_{2} \mathrm{O}: 6.10$ and 5.50; $\mathrm{Al}: 0.00$ and $0.10 \mathrm{cmol}_{\mathrm{c}} \mathrm{dm}^{-3}$; $\mathrm{H}: 3.63$ and $4.03 \mathrm{cmol}_{\mathrm{c}} \mathrm{dm}^{-3}$; and contents of $\mathrm{P}, \mathrm{K}, \mathrm{Ca}$ and Mg: 2.09 and $1.18 \mathrm{mg} \mathrm{dm}^{-3} ; 22.0$ and $19.0 \mathrm{mg} \mathrm{dm}^{-3} ; 1.97$ and $0.62 \mathrm{cmol}_{\mathrm{c}} \mathrm{dm}^{-3} ; 0.78$ and $0.31 \mathrm{cmolc} \mathrm{dm}^{-3}$, respectively; base saturation (V): 43.63 and 19.27\%; CEC at $\mathrm{pH} 7.0$ : 6.44 and $5.12 \mathrm{cmol}_{\mathrm{c}} \mathrm{dm}^{-3}$, respectively.

Based on soil analysis and recommendations of Trani et al. (2014), 1.5 L of aged bovine manure as organic fertilization, $100 \mathrm{~g}$ of the 4-14-8 NPK fertilizer and $20 \mathrm{~g}$ of dolomitic limestone were applied per hole.

As to physical properties, the soil had in the $0-20$ and 20 $40 \mathrm{~cm}$ layers the following proportions: 341 and 300; 167 and 188; 492 and $512 \mathrm{~g} \mathrm{dm}^{-3}$ of sand, silt and clay, respectively. For physical-hydraulic properties, in the $0-10,10-20$ and $20-40 \mathrm{~cm}$ layers, the values were: soil density - 1.21, 1.14 and $1.05 \mathrm{~g} \mathrm{~cm}^{-3}$; total porosity $-42.54,46.85$ and $52.89 \%$; moisture at $30 \mathrm{kPa}$ - 33.99, 31.36 and 32.61\%; and moisture at $500 \mathrm{kPa}-17.09$, 19.55 and $17.55 \%$, respectively. Soil water retention curve was determined using the model proposed by Genuchten (1980) in the soil layers $(0-0.1 ; 0.1-0.2 ; 0.2-0.4 \mathrm{~m})$, with dependence of matric potential $\left(\Psi_{\mathrm{m}}\right)$, obtaining the following equations: $\theta_{0-10}=0.13633+0.034593 /\left\{\left[1+\left(0.037489 \Psi_{\mathrm{m}}\right)^{1.539778}\right]^{0.350556}\right\}$; $\theta_{10-20}=0.169113+0.026375 /\left\{\left[1+\left(0.356867 \Psi_{\mathrm{m}}^{\mathrm{m}}\right)^{1.350717}\right]^{0.259652}\right\}$; $\theta_{20-40}=0.134981+0.040544 /\left\{\left[1+\left(0.496512 \Psi_{\mathrm{m}}\right)^{1.307941}\right]^{0.23544}\right\}$, respectively.

Drip irrigation system was used, with pressurecompensating drippers spaced by $0.5 \mathrm{~m}$, flow rate of $3.0 \mathrm{~L} \mathrm{~h}^{-1} \mathrm{~m}^{-1}$ and service pressure of 10 m.w.c. Potential evapotranspiration was determined by the soil water balance, daily monitored through tensiometry using digital tensiometers, in four replicates of three tensiometers at depths of $0.1,0.2$ and $0.4 \mathrm{~m}$, per plot. 
After defining the potential evapotranspiration of the crop (ETc) by the variation in the volumetric moisture levels in the soil layers, crop coefficients $(\mathrm{Kc})$ were defined by the ratio between ETc and reference evapotranspiration $\left(\mathrm{ET}_{0}\right)$ obtained by the FAO-56 Penman-Monteith method (Allen et al., 1998). In the analysis of Kc values, crop phenological stages were grouped into stages I, II, III and IV, which correspond to periods from sowing to $10 \%$ maximum number of leaves, from 10 to $80 \%$ maximum number of leaves, from $80 \%$ maximum number of leaves to the peak of harvest, and from peak of harvest to leaf senescence, respectively.

To evaluate the production response function with respect to the irrigation depth, irrigation management was based on the application of 40,60,80,100 (reference) and $120 \% \mathrm{ETc}$, calculated as the product between $\mathrm{Kc}$ and $\mathrm{ET}_{0}$ obtained by the Class A pan method, considering the pan correction coefficient (kp) as 0.78 (Souza et al., 2015). In this case, the pre-determined values of $\mathrm{Kc}$ from experiment 1 were considered, for the same day after sowing (DAS). The evaluations of production performance, phenological stages and water requirement were carried out based on the thermal sum proposed by Ometto (1981), using the lower and upper basal temperatures of 12 and $36^{\circ} \mathrm{C}$.

Production performance was evaluated based on water use efficiency (WUE), considering the water volumes from irrigation depth and rainfall in the fresh weight production of summer squash fruits and only the water volume applied through irrigation (El-Wahed et al., 2017).

The data were subjected to analysis of variance and, when significant, means were compared by Tukey test at 0.05
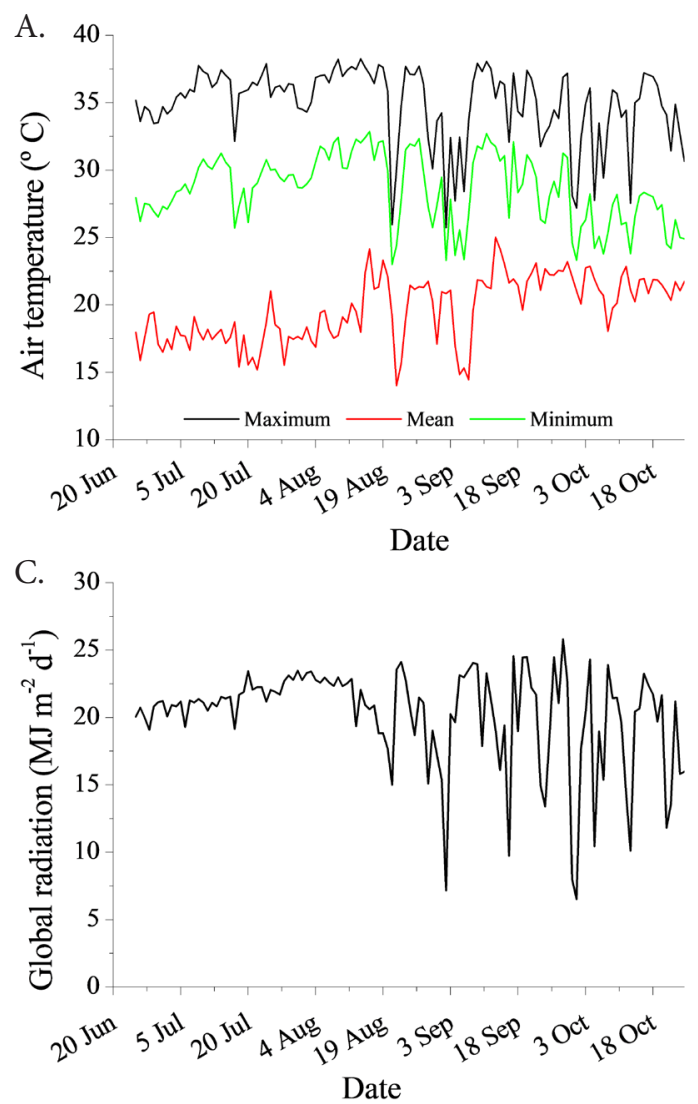

probability level, whereas regressions were fitted considering the cumulative thermal sum or the irrigation depth as independent variables.

\section{Results AND Discussion}

In the experimental period, cumulative rainfalls amounted to $185 \mathrm{~mm}, 51.4 \%$ of which occurred from 10/05/2016 (Figure 1). In this context, soil moisture homogenization in treatments with different irrigation depths was higher from 75 DAP, i.e., 34 days after the beginning of the harvests, indicating that the effect of irrigation depths was evaluated mainly on the cumulative production. In addition, atmospheric transmissivity decreased, with means of 21.52, 21.18, 19.75 and $18.1 \mathrm{MJ} \mathrm{m}^{-2} \mathrm{~d}^{-1}$ of global radiation between July and October.

Maximum and minimum temperatures were 38.25 and $14.02{ }^{\circ} \mathrm{C}$, and in this case there was limitation in the daily thermal sum by the upper basal temperature $\left(36^{\circ} \mathrm{C}\right)$ equal to 55 days along the experimental period. Daily means of air temperature oscillated from 23.0 to $32.9{ }^{\circ} \mathrm{C}$, whereas daily mean relative air humidity varied from 29.32 to $97.1 \%$, with minimum of $15.48 \%$ on $08 / 09 / 2016$. In addition, there was also a significant reduction in daily thermal amplitude with the beginning of the rainfalls.

Cumulative ETc along the crop cycle was 116.06, 116.23 and $111.69 \mathrm{~mm}$ for the mulch managements with millet, crotalaria and bare soil, respectively, whereas cumulative ETo in the same period was equal to $483.89 \mathrm{~mm}$. The small differences in ETc between soil covers may result from the fast growth of the crop, which completely covered the planting row (where

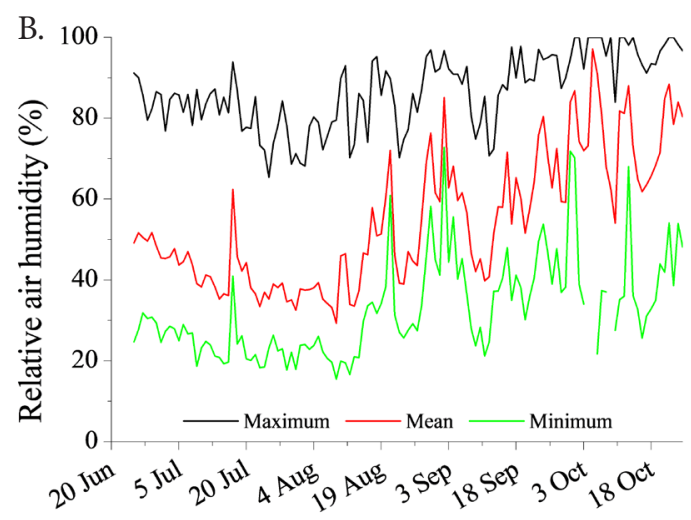

Date

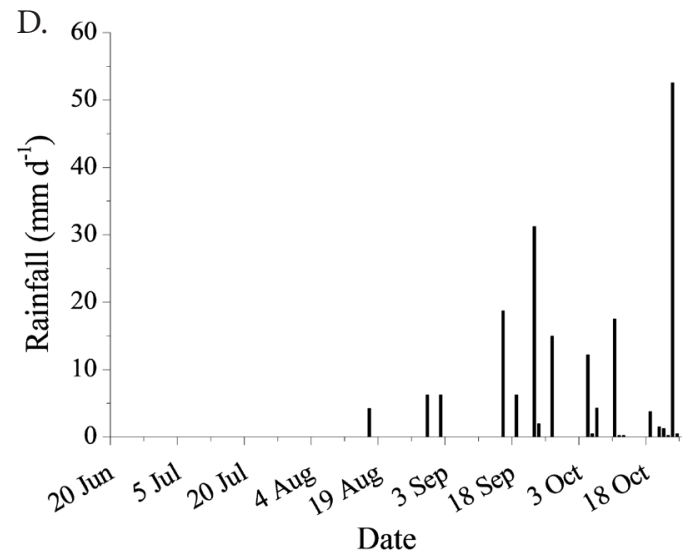

Figure 1. Variations in air temperature $(A)$, relative air humidity $(B)$, global radiation $(C)$ and rainfall $(D)$ in Sinop, MT, Brazil, between 25/06/2016 and 25/10/2016 
tensiometers were installed), reducing water evaporation in the soil, associated also with the daily irrigation management based on the matric potential, which kept the soil at field capacity, regardless of mulching condition, and minimized its effect on the reduction of evaporation and maintenance of water in the soil. In addition, the similar cumulative behavior of ETc under the cultivation conditions with straw can be associated with low rates of decomposition of the plant residues when subjected to drip irrigation (Souza et al., 2014; El-Wahed et al., 2017).

In general, differences in evapotranspiration for a same crop can occur due to its growth responses to the local climate and soil physical-hydraulic conditions, and also due to the method used to obtain ETc. Klosowski et al. (1999), using constant water table lysimeters in Botucatu, SP, obtained cumulative ETc of $231.52 \mathrm{~mm}$ for summer squash cv. 'Italiana' along 70 days of cycle. Kuslu et al. (2014), applying the Class A pan method in Turkey, obtained ETc from 297.1 to $452.9 \mathrm{~mm}$, for 95 -day cycles of C. pepo.

Kc values were similar between soil covers, varying from 0.08 to 0.60 along the 87 DAS (Figure 2). Daily variations of Kc for the three treatments were described by decreasing quadratic polynomials, which indicate maximum points between 1200 and 1300 degree-days and maximum Kc values lower than 0.60 . Recently, various studies on the interaction between mulching and irrigation indicated that the use of mulch allows the application of lower irrigation depths, leading to crop coefficients lower than that for cultivation in bare soil (Carvalho et al., 2016, 2018).

Regardless of soil cover, leaf senescence (cycle duration) occurred at 89 DAS. According to the recommendations of Allen et al. (1998), the durations for the stages I, II, III and IV of summer squash are about 20,30, 30 and 20 days, respectively, totaling 100 days.

Mean Kc values increased along the phenological stages and could be grouped as means of $0.10,0.25,0.38$ and 0.40 for the stages I, II, III and IV, respectively (Table 1). These values are lower than those proposed by Allen et al. (1998), who recommend for cucurbits mean Kc values of $0.5,1.0$ and 0.80 for the stages I, III and IV, respectively.

Yavuz et al. (2015b) obtained mean Kc values of 0.56, 0.72, 0.95 and 0.65 for the above-mentioned stages, when irrigation intervals of 7 days are used. Klosowski et al. (1999) obtained Kc of $0.68,1.96$ and 1.38 in the first, sixth and tenth weeks of the cycle of summer squash cv. 'Italiana'. The differences between Kc values obtained for a same crop may result from the form of $\mathrm{ET}_{0}$ determination, since the models/methods may lead to under- or overestimations for different temporal partitions.

In general, when plants are exposed to water deficit conditions, there are physiological responses which can indirectly result in water conservation in the soil, because of the
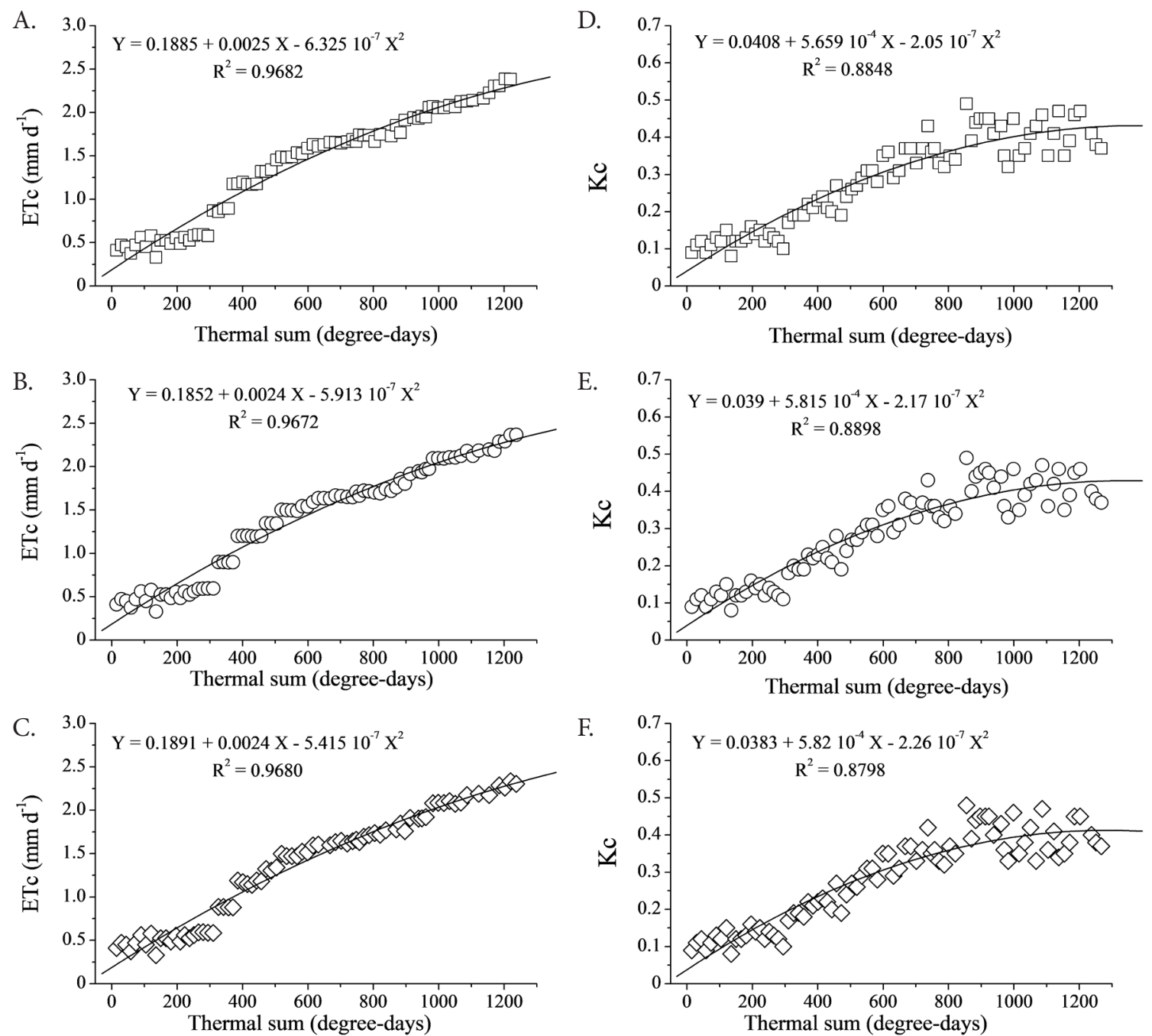

Figure 2. Evapotranspiration $\left(\mathrm{mm} \mathrm{d}^{-1}\right)$ and crop coefficients of summer squash cv. 'Italiana', subjected to mulching with millet (A, D), crotalaria (B, E) and bare soil (C, F), in Sinop, MT, Brazil, between 25/06/2016 and 09/10/2016 
Table 1. Cumulative thermal sum (degree-days) and crop coefficients $(\mathrm{Kc})$ in different growth stages of summer squash cv. 'Italiana' subjected to different soil covers, in Sinop, MT, Brazil

\begin{tabular}{lccccc}
\hline & Soil & \multicolumn{4}{c}{ Stage } \\
\cline { 3 - 6 } & cover & I & II & III & IV \\
\multirow{2}{*}{$\begin{array}{l}\text { Degree- } \\
\text { Millet }\end{array}$} & $120.38(8)^{*}$ & $666.55(46)$ & $229.04(16)$ & $317.12(19)$ \\
days & Crotalaria & $120.38(8)$ & $666.55(46)$ & $228.26(14)$ & $350.72(21)$ \\
& Bare soil & $120.38(8)$ & $700.68(48)$ & $246.91(17)$ & $265.12(16)$ \\
\multirow{3}{*}{ Kc } & Millet & $0.1 \pm 0.035$ & $0.25 \pm 0.088$ & $0.38 \pm 0.045$ & $0.41 \pm 0.088$ \\
& Crotalaria & $0.1 \pm 0.036$ & $0.25 \pm 0.087$ & $0.38 \pm 0.043$ & $0.41 \pm 0.088$ \\
& Bare soil & $0.1 \pm 0.035$ & $0.26 \pm 0.086$ & $0.37 \pm 0.047$ & $0.39 \pm 0.093$ \\
\hline
\end{tabular}

*Indicates phenological stage duration in days; Stage I - From sowing to $10 \%$ number of leaves; Stage II - From 10 to $80 \%$ number of leaves; Stage III - From $80 \%$ number of leaves to peak of harvest; Stage IV - From peak of harvest to leaf senescence

reduction in transpiring surface due to senescence, decrease in leaf expansion or elongation, which are processes that depend on turgor and water availability to plants (Epstein \& Bloom, 2006).

In addition, depending on the irrigation system adopted, low irrigation depths can promote mulch hydration, decreasing the quantity of water available in the soil to the crop (Souza et al., 2014). Since ETc, and consequently Kc, depends on climatic factors, management and plant, the association between water deficit and mulch may generate conditions for physiological adaptations that do not alter Kc values significantly in crops with straw on the surface. However, these responses depend on crop cycle and rate of decomposition of the plant residues used.

The type of soil cover had significant effect at 84 DAS only for the $60 \%$ ETc irrigation depth (Table 2), with lower mean values in the bare soil condition. Irrigation depths did not influence stem diameter, regardless of soil cover, whereas significant differences in the number of leaves were only found in the cultivation with millet straw.

In general, the irrigation depth of $60 \%$ ETc led to highest mean values for the cultivation conditions with straw, whereas in bare soil the highest means of morphometric variables were obtained at the highest irrigation depths.

No significant differences were found between irrigation depths and between the soil covers and the thermal requirements
Table 2. Morphometric variables of summer squash cv. 'Italiana' subjected to different irrigation depths and soil covers, at 84 days after sowing, in Sinop, MT, Brazil

\begin{tabular}{cccccc}
\hline $\begin{array}{c}\text { Soil } \\
\text { covers }\end{array}$ & $\begin{array}{c}\text { Irrigation } \\
\text { depth } \\
\text { (\% ETc) }\end{array}$ & $\begin{array}{c}\text { Plant } \\
\text { height } \\
\text { (cm) }\end{array}$ & $\begin{array}{c}\text { Leaf } \\
\text { area } \\
\left.\mathbf{( c m}^{2}\right)\end{array}$ & $\begin{array}{c}\text { Stem } \\
\text { diameter } \\
\text { (mm) }\end{array}$ & $\begin{array}{c}\text { Number } \\
\text { of leaves }\end{array}$ \\
& 40 & $39.7 \mathrm{Ab}$ & $1,484.2 \mathrm{Ab}$ & $13.2 \mathrm{Aa}$ & $16.7 \mathrm{Ab}$ \\
Millet & 60 & $69.3 \mathrm{Aa}$ & $8,501.8 \mathrm{Aa}$ & $15.7 \mathrm{Aa}$ & $31.7 \mathrm{Aa}$ \\
& 80 & $51.7 \mathrm{Aab}$ & $4,344.7 \mathrm{Aab}$ & $11.6 \mathrm{Aa}$ & $28.3 \mathrm{Aab}$ \\
& 100 & $54.0 \mathrm{Aab}$ & $5,808.3 \mathrm{Aab}$ & $12.7 \mathrm{Aa}$ & $29.0 \mathrm{Aa}$ \\
& 120 & $48.7 \mathrm{Aab}$ & $5,813.6 \mathrm{Aab}$ & $11.4 \mathrm{Aa}$ & $23.7 \mathrm{Aab}$ \\
& 40 & $28.2 \mathrm{Ab}$ & $2,405.7 \mathrm{Ab}$ & $10.3 \mathrm{Aa}$ & $15.7 \mathrm{Aa}$ \\
Crotalaria & 60 & $56.7 \mathrm{Aa}$ & $6,358.9 \mathrm{Aa}$ & $14.0 \mathrm{Aa}$ & $23.3 \mathrm{Aa}$ \\
& 80 & $34.7 \mathrm{Aab}$ & $2,485.3 \mathrm{Ab}$ & $10.9 \mathrm{Aa}$ & $16.0 \mathrm{Aa}$ \\
& 100 & $53.0 \mathrm{Aab}$ & $3,555.9 \mathrm{Aab}$ & $12.4 \mathrm{Aa}$ & $19.0 \mathrm{Aa}$ \\
& 120 & $39.0 \mathrm{Aab}$ & $2,587.8 \mathrm{Ab}$ & $10.4 \mathrm{Aa}$ & $17.0 \mathrm{Aa}$ \\
\hline & 40 & $20.0 \mathrm{Ab}$ & $1,417.7 \mathrm{Ab}$ & $6.9 \mathrm{Ba}$ & $15.7 \mathrm{Aa}$ \\
Bare soil & 60 & $36.7 \mathrm{Bab}$ & $1,906.4 \mathrm{Bb}$ & $7.3 \mathrm{Ba}$ & $17.3 \mathrm{Ba}$ \\
& 80 & $45.8 \mathrm{Aa}$ & $2,784.0 \mathrm{Aab}$ & $12.2 \mathrm{Aa}$ & $21.3 \mathrm{Aa}$ \\
& 100 & $33.3 \mathrm{Aab}$ & $2,901.1 \mathrm{Aab}$ & $11.7 \mathrm{Aa}$ & $25.3 \mathrm{Aa}$ \\
\hline & 120 & $43.2 \mathrm{Aa}$ & $4,295.1 \mathrm{Aa}$ & $11.9 \mathrm{Aa}$ & $24.0 \mathrm{Aa}$ \\
\hline
\end{tabular}

Means followed by the same uppercase letters do not differ between soil covers for the same irrigation depth and means followed by lowercase letters do not differ between irrigation depths for the same soil cover, by Tukey test at 0.05 probability level

for the beginning of the production of male and female flowers (Table 3). Soil cover with millet straw caused higher number of male flowers, except at irrigation depth of $120 \%$ ETc. The ratios between female and male flowers varied from 1:0.94 to 1:1.98. Fruit fresh weights varied from 402.5 to $515.3 \mathrm{~g}$, and the lowest means were obtained in the bare soil condition (except for the $60 \%$ ETc irrigation depth). Such variation resulted from the commercial standard adopted for fruit harvest.

Yields were higher in the conditions with mulch, except for the $40 \%$ ETc irrigation depth. Yield increments varied from 31 to $55 \%$ (100 and 60\% ETc irrigation depths) in cultivation with millet straw and from 3.7 to $51 \%$ (100 and 80\% ETc irrigation depths) in cultivation with crotalaria straw, compared with the bare soil condition.

Considering only the irrigation depth, the quadratic functions were significant at 0.05 probability level in the

Table 3. Thermal requirements (degree-days) for different reproductive phenological stages of summer squash cv. 'Italiana' subjected to different irrigation depths and mulches, between 0 and 84 days after sowing, in Sinop, MT, Brazil

\begin{tabular}{|c|c|c|c|c|c|c|c|}
\hline $\begin{array}{l}\text { Irrigation depth } \\
\text { (\% ETc) }\end{array}$ & MF start & FF start & $\begin{array}{l}\text { Total number } \\
\text { of MF per plant }\end{array}$ & $\begin{array}{l}\text { Total number } \\
\text { of FF per plant }\end{array}$ & MF/FF ratio & $\begin{array}{l}\text { Fruit mean } \\
\text { weight }(\mathrm{g})\end{array}$ & $\begin{array}{c}\text { Yield } \\
\left(\mathrm{Mg} \mathrm{ha}^{-1}\right)\end{array}$ \\
\hline \multicolumn{8}{|c|}{ Millet } \\
\hline 40 & 597.26 & 660.21 & $13.60 \mathrm{Aa}$ & 7.80 & 1.74 & $447.4 \mathrm{Aa}$ & $10.99 \mathrm{~A}$ \\
\hline 60 & 582.47 & 597.26 & $13.90 \mathrm{Aa}$ & 8.30 & 1.67 & $448.9 \mathrm{Aa}$ & $14.37 \mathrm{~A}$ \\
\hline 80 & 582.47 & 597.26 & $12.50 \mathrm{Aa}$ & 8.60 & 1.45 & $459.9 \mathrm{Aa}$ & $16.27 \mathrm{~A}$ \\
\hline 100 & 582.47 & 582.47 & $14.40 \mathrm{Aa}$ & 8.60 & 1.67 & $496.5 \mathrm{ABa}$ & $17.38 \mathrm{~A}$ \\
\hline 120 & 582.47 & 582.47 & $9.30 \mathrm{Bb}$ & 7.40 & 1.26 & $490.0 \mathrm{Aa}$ & $20.21 \mathrm{~A}$ \\
\hline 40 & 582.47 & 660.21 & $13.90 \mathrm{Aa}$ & 7.80 & 1.78 & $420.9 \mathrm{Aa}$ & $10.40 \mathrm{~A}$ \\
\hline 60 & 597.26 & 613.35 & $10.70 \mathrm{Ba}$ & 7.00 & 1.53 & $434.9 \mathrm{Aa}$ & $11.40 \mathrm{AB}$ \\
\hline 80 & 582.47 & 613.35 & $10.70 \mathrm{Ba}$ & 11.30 & 0.94 & $441.3 \mathrm{ABa}$ & $17.58 \mathrm{~A}$ \\
\hline 100 & 582.47 & 582.47 & $13.70 \mathrm{Aa}$ & 8.70 & 1.57 & $515.3 \mathrm{Aa}$ & $13.74 \mathrm{~B}$ \\
\hline 120 & 582.47 & 597.26 & $12.90 \mathrm{Aa}$ & 7.50 & 1.72 & $445.4 \mathrm{ABb}$ & $14.48 \mathrm{~B}$ \\
\hline \multicolumn{8}{|c|}{ Bare soil } \\
\hline 40 & 597.26 & 660.21 & $10.50 \mathrm{Ba}$ & 6.40 & 1.64 & $404.5 \mathrm{Ab}$ & $8.29 \mathrm{~A}$ \\
\hline 80 & 597.26 & 660.21 & $11.90 \mathrm{ABa}$ & 8.70 & 1.37 & $402.5 \mathrm{Bb}$ & $11.57 \mathrm{~B}$ \\
\hline 100 & 582.47 & 613.35 & $10.70 \mathrm{Ba}$ & 7.90 & 1.35 & 461.3 Bab & $13.26 \mathrm{~B}$ \\
\hline 120 & 582.47 & 613.35 & $12.80 \mathrm{Aa}$ & 6.80 & 1.88 & 415.3 Bab & $13.15 \mathrm{~B}$ \\
\hline
\end{tabular}

MF - Male flowers; FF - Female flowers; Means followed by the same uppercase letters do not differ between soil covers for the same irrigation depth and means followed by lowercase letters do not differ between irrigation depths for the same soil cover, by Tukey test at 0.05 probability level 
condition with millet straw and bare soil. Maximum yields estimated by the models were 24.7, 15.4 and $13.9 \mathrm{Mg} \mathrm{ha}^{-1}$ for the cover with millet, crotalaria and bare soil, respectively (Figure 3).

Yield depends on the number of fruits and fruit mean weight, and in this case the main difference observed between treatments was in the number of fruits per plant. Nevertheless, in general, as the water deficit increases there is a trend of reduction in fruit weight, as observed by Bilibio et al., (2011), Martin-Vertedor et al. (2011), Lima et al. (2013) and Sousa et al. (2014) for rapeseed, olive, Cayenne pepper and peanut, respectively.

The reduction observed in fruit weight and yield of summer squash, according to Fernandes et al. (2014), can be associated with irrigation intervals longer than one day, which can cause water deficit periods between two successive irrigation. Specifically for 'Italiana' summer squash, Garcia (2015) observed that the increase in irrigation interval and suspension of irrigation from 55 days after planting caused reduction in fruit length, fruit weight and yield of summer squash, whereas under conditions of daily replacement of irrigation the yield was approximately $25.0 \mathrm{Mg} \mathrm{ha}^{-1}$.
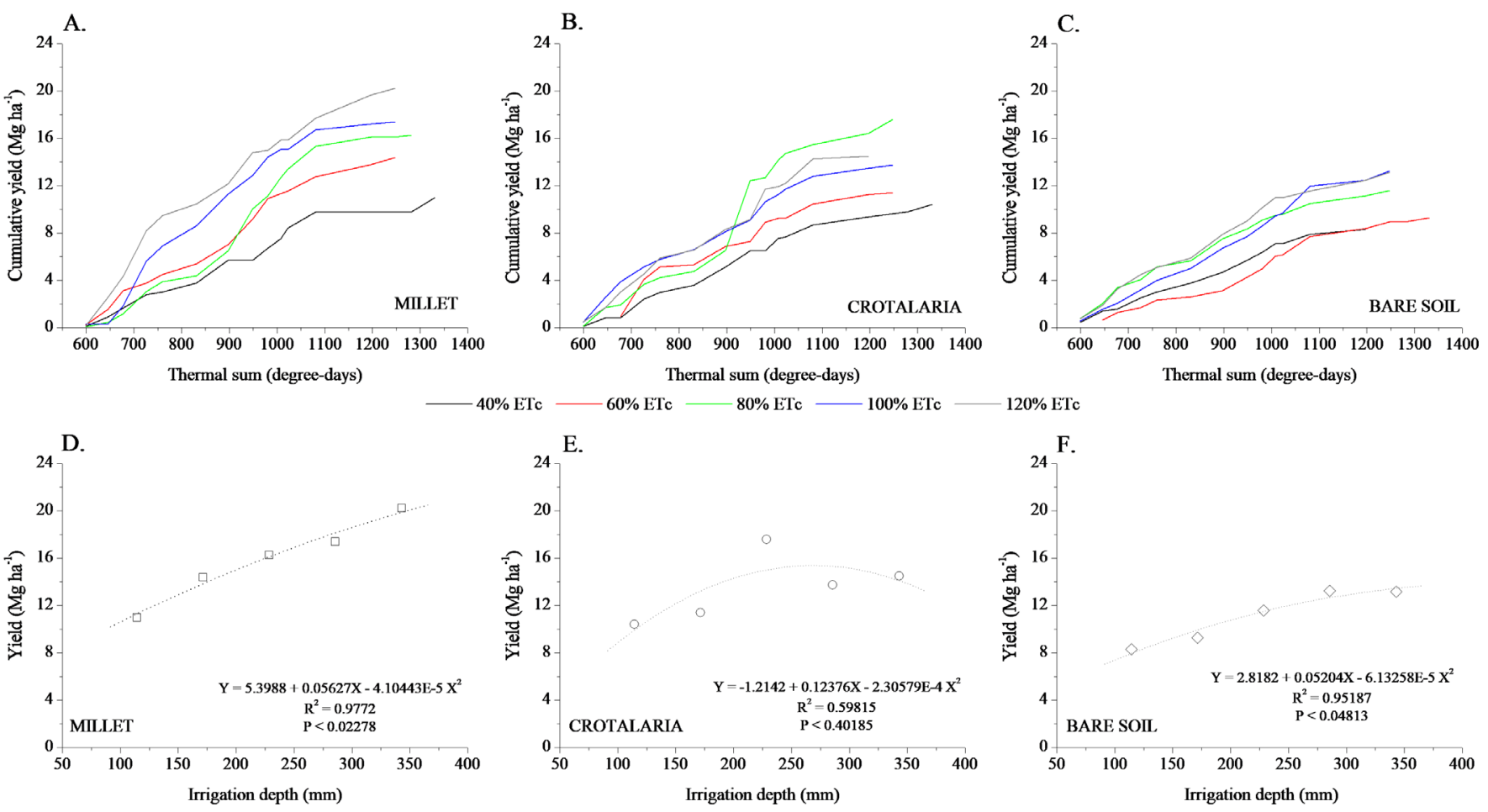

G.
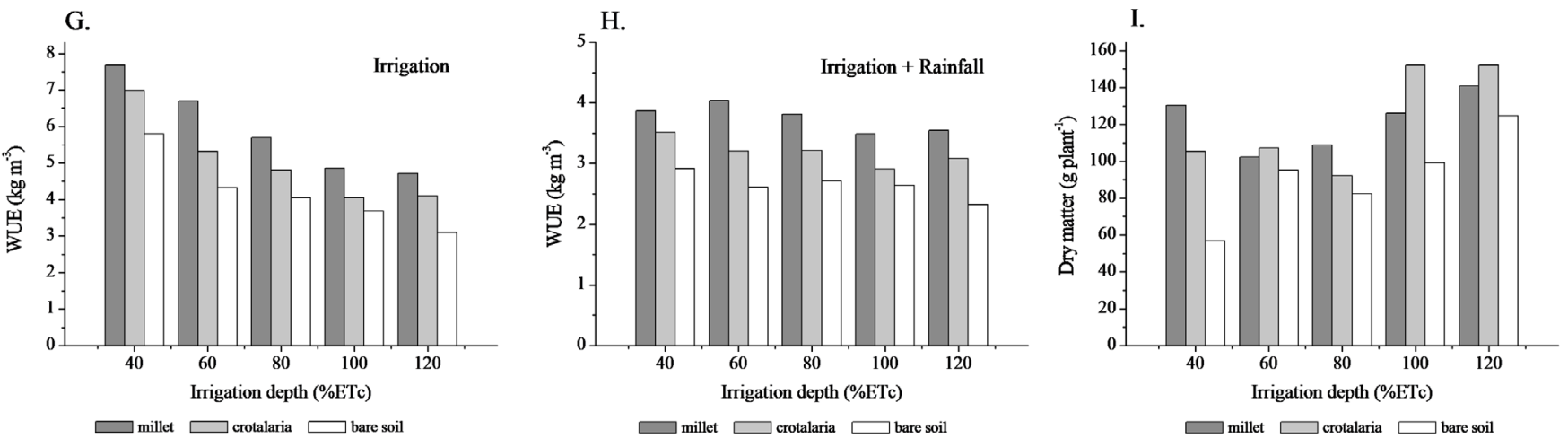

Figure 3. Cumulative yield (A, B and C), water response functions (D, E and F), water use efficiency $(G$ and $H)$ and dry matter per plant (I) of summer squash cV. 'Italiana' subjected to different mulches and irrigation depths, in Sinop, MT, Brazil 
et al. (2005), evaluating replacements of 60, 80, 100 and $120 \%$ reference evapotranspiration, obtained positive linear correlations between production components and irrigation depths and decreasing WUE values with the increase in the applied water volume. Kuslu et al. (2014), using three values of the product between Kc and kp (Kcp of 1.0, 0.85 and 0.70), observed that smaller water volumes led to lower values of yield and production components.

\section{Conclusions}

1. Soil cover does not influence evapotranspiration, crop coefficients and cumulative thermal sum in the phenological stages of summer squash cv. 'Italiana' cultivated in the MidNorth region of Mato Grosso.

2. The mean crop coefficients of summer squash cv. 'Italiana' are $0.10,0.25,0.38$ and 0.40 for four phenological stages with durations of $8,46,16$ and 180 days or cumulative thermal sums of 120, 670, 230 and 320 degree-days, respectively.

3 . Increase in irrigation depth and presence of mulch on the soil do not influence the production rates and proportions of male and female flowers of summer squash cv. 'Italiana'.

4. Increase in irrigation depth reduces water use efficiency, regardless of soil cover.

\section{Literature Cited}

Allen, R. G.; Pereira, L. S.; Raes, D.; Smith, M. Crop evapotranspiration: Guidelines for computing crop water requirements. Rome: FAO, 1998. 300p. Irrigation and Drainage Paper, 56

Al-Omran, A. M.; Sheta, A. S.; Falatah, A. M.; Al-Harbi, A. R. Effect of drip irrigation on squash (Curcubita pepo) yield and water-use efficiency in sandy calcareous soils amended with clay deposits. Agricultural Water Management, v.73, p.43-55, 2005. https://doi. org/10.1016/j.agwat.2004.09.019

Amer, K. H. Effect of irrigation method and quantity on squash yield and quality. Agricultural Water Management, v.98, p.1197-1206, 2011. https://doi.org/10.1016/j.agwat.2011.03.003

Amer, K. H.; Midan, S. A.; Hatfield, J. L. Effect of deficit irrigation and fertilization on cucumber. Agronomy Journal, v.101, p.1556-1564, 2009. https://doi.org/10.2134/agronj2009.0112

Bilibio, C.; Carvalho, J. de A.; Hensel, O.; Richter, U. Effect of different levels of water deficit on rapeseed (Brassica napus L.) crop. Ciência e Agrotecnologia, v.35, p.672-684, 2011. https://doi.org/10.1590/ S1413-70542011000400005

Carvalho, D. F. de; Pinto, M. F.; Monte, J. A.; Mello, G. A. B. de; Sousa, C. P. de. Water use efficiency and economic return of fresh vegetable in organic cultivation. Revista Brasileira de Engenharia Agrícola e Ambiental, v.20, p.637-642, 2016. https:// doi.org/10.1590/1807-1929/agriambi.v20n7p637-642

Carvalho, D. F. de; Ribeiro, E. C.; Gomes, D. P. Marketable yield of onion under different irrigation depths, with and without mulch. Revista Brasileira de Engenharia Agrícola e Ambiental, v.22, p.107-122, 2018. https://doi.org/10.1590/1807-1929/agriambi. v22n2p107-112

Echer, M. de M.; Dalastra, G. M.; Hachmann, T. L.; Fiametti, M. S.; Guimarães, V. F.; Oliveira, P. S. R. Características produtivas e qualitativas de mini abóbora em dois sistemas de cultivo. Horticultura Brasileira, v.32, p.286-291, 2014. https://doi. org/10.1590/S0102-05362014000300008
El-Wahed, M. H.; Baker, G. A.; Ali, M. M.; El-Fattah, F. A. A. Effect of drip déficit irrigation and soil mulching on growth of common bean plant, water use efficiency and soil salinity. Scientia Horticulturae, v.225, p.235-242, 2017. https://doi.org/10.1016/j. scienta.2017.07.007

EMBRAPA - Empresa Brasileira de Pesquisa Agropecuária. Centro Nacional de Pesquisa de Solos. Sistema brasileiro de classificação de solos. 3.ed. Rio de Janeiro: Embrapa Solos, 2013. 353p.

Epstein, E.; Bloom, A. J. Nutrição mineral de plantas. Londrina: Planta, 2006. 401p.

Ertek, A.; Sensoy, S.; Küçükyumuk, C.; Gedik, I. Irrigation frequency and amount affect yield components of summer squash (Curcubita реро L.). Agricultural Water Management, v.67, p.63-76, 2004. https://doi.org/10.1016/j.agwat.2003.12.004

Fernandes, C. N. V.; Azevedo, B. M. de; Nascimento Neto, J. R. do; Viana, T. V. de A.; Campelo, A. R. Desempenho produtivo e econômico da cultura da melancia submetida a diferentes turnos de rega. Irriga, v.19, p.149-159, 2014. https://doi.org/10.15809/ irriga.2014v19n1p149

Garcia, A. C. Supressão e frequência de irrigação na cultura da abobrinha. Fortaleza: UFC, 2015. 66p. Dissertação Mestrado

Genuchten, M. T. van. A closed-form equation for predicting the conductivity of unsatured soils. Soil Science Society of America Journal, v.44, p.892-898, 1980. https://doi.org/10.2136/ sssaj1980.03615995004400050002x

Klosowski, E. S.; Lunardi, D. M. C.; Sandanielo, A. Determinação do consumo de água e do coeficiente de cultura da abóbora na região de Botucatu, SP. Revista Brasileira de Engenharia Agrícola e Ambiental, v.3, p.409-412, 1999. https://doi.org/10.1590/18071929/agriambi.v3n3p409-412

Kuslu, Y.; Sahin, U.; Kiziloglu, F. M.; Memis, S. Fruit yield and quality, and irrigation water use efficiency of summer squash drip-irrigated with different irrigation quantities in a semi-arid agricultural area. International of Integrative Agriculture, v.13, p.2518-2526, 2014. https://doi.org/10.1016/S2095-3119(13)60611-5

Lima, E. M. de C.; Carvalho, J. de A.; Rezende, F. C.; Thebaldi, M. S.; Gatto, R. F. Rendimento da pimenta cayenne em função de diferentes tensões de água no solo. Revista Brasileira de Engenharia Agrícola Ambiental, v.17, p.1181-1187, 2013. https:// doi.org/10.1590/S1415-43662013001100008

Martin-Vertedor, A. J.; Rodrigues, J. M. P.; Losada, H. P.; Castiel, E. F. Interactive responses to water deficits and crop load in olive (Olea europaea L.). II: Water use, fruit and oil yield. Agricultural Water Management, v.98, p.950-858, 2011. https://doi.org/10.1016/j. agwat.2011.01.003

Maughan, T.; Drost, D.; Allen, L. N. Vegetable irrigation: Squash and pumpkin. Logan: All Current Publications, 2015. 5p. Paper 745

Ometto, J. C. Bioclimatologia vegetal. São Paulo: Agronômica Ceres, 1981. 425p.

Román-Paoli, E.; Martínez-Garrastazú, S.; Flores, L.; Almodóvar, L. Pumpkin response to microirrigation in two agro-ecologial regions in Puerto Rico. The Journal of Agricultural of the University of Puerto Rico, v.96, p.139-153, 2012.

Seymen, M.; Yavuz, D.; Yavuz, N.; Türkmen, Ö. Effect on yield and yield components of different irrigation levels in edible seed pumpkin growing. International Scholarly and Scientific Research \& Innovation, v.10, p.275-280, 2016. 
Sousa, G. G. de; Azevedo, B. M. de; Lima, R. H.; Silva, J. E. da; Viana, T. V. da A. Growth and yield of peanut with different irrigation levels applied by drip irrigation. Irriga, v.19, p.186-195, 2014. https://doi.org/10.15809/irriga.2014v19n2p186

Souza, A. P. de; Almeida, F. T. de; Arantes, K. R.; Marcim, C. C.; Silva, J. O. da. Coeficientes de tanque classe A para estimativa da evapotranspiração de referência diária na região de transição Cerrado-Amazônia. Scientia Plena, v.11, p.1-13, 2015.

Souza, A. P. de; Carvalho, D. F. de; Silva, L. B. D. da; Guerra, J. G. M.; Costa, J. R. Taxas de decomposição de resíduos vegetais submetidos a lâminas de irrigação. Irriga, v.19, p.512-526, 2014. https://doi.org/10.15809/irriga.2014v19n3p512

Souza, A. P. de; Mota, L. L.; Zamadei, T.; Martim, C. C.; Almeida, F. T.; Paulino, J. Classificação climática e balanço hídrico climatológico no estado de Mato Grosso. Nativa, v.1, p.34-43, 2013. https://doi. org/10.14583/2318-7670.v01n01a07
Teixeira, P. C.; Donagemma, G. K.; Fontana, A.; Teixeira, W. G. Manual de métodos de análise de solo. 3.ed. rev. e ampl. Brasília: Embrapa Informação Tecnológica, 2017. 573p.

Trani, P. E.; Passos, F. A.; Araújo, H. S. de. Calagem e adubação da abobrinha italiana (de moita) (Curcubita pepo), abóbora brasileira (Curcubita moschata), moranga (Curcubita maxima) e abóbora japonesa (híbrida). Campinas: Instituto Agronômico de Campinas, 2014. 8p. Documentos, 31

Yavuz, D.; Seymen, M.; Yavuz, N.; Türkmen, Ö. Effects of irrigation interval and quantity on the yield and quality of confectionary pumpkin grown under field conditions. Agricultural Water Management, v.159, p.290-298, 2015a. https://doi.org/10.1016/j. agwat.2015.06.025

Yavuz, D.; Yavuz, N.; Seymen, M.; Türkmen, Ö. Evapotranspiration, crop coefficient and seed yield of drip irrigated pumpkin under semi-arid conditions. Scientia Horticulturae, v.197, p.33-40, 2015b. https://doi.org/10.1016/j.scienta.2015.11.010 